Interfaces

\title{
Each painting is a fragment of a painting of infinite dimensions that we never finish
}

Interview with artist/novelist Fernando del Paso

\section{Donald Friedman}

\section{OpenEdition}

\section{Journals}

Electronic version

URL: https://journals.openedition.org/interfaces/4014

DOI: 10.4000/interfaces.4014

ISSN: 2647-6754

\section{Publisher:}

Université de Bourgogne, Université de Paris, College of the Holy Cross

\section{Electronic reference}

Donald Friedman, "Each painting is a fragment of a painting of infinite dimensions that we never finish", Interfaces [Online], 46 | 2021, Online since 15 December 2021, connection on 17 June 2022. URL: http://journals.openedition.org/interfaces/4014 ; DOI: https://doi.org/10.4000/interfaces.4014

This text was automatically generated on 17 June 2022 .

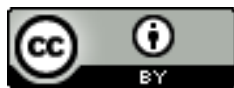

Les contenus de la revue Interfaces sont mis à disposition selon les termes de la Licence Creative Commons Attribution 4.0 International. 


\title{
Each painting is a fragment of a painting of infinite dimensions that we never finish
}

\author{
Interview with artist/novelist Fernando del Paso
}

\section{Donald Friedman}

Fernando del Paso, "I Dream that I Paint, and I Paint the Dream." - YouTube

2 Acclaimed novelist and essayist, Fernando del Paso in 2015 joined the company of literary greats, Jorge Luis Borges, Rafael Alberti, Carlos Fuentes, and Nobelists Octavio Paz and Mario Vargas Llosa, when he received the Cervantes Prize, the most prestigious award for Spanish-language literature. From his nine-hundred-page first novel, Jose Trigo (1966) to his other widely translated, encyclopedic, linguistically obsessive, semimagical Palinuro de Mexico (1977) and Noticias del Imperio (1987), he achieved wide critical success. The Surrealist-influenced del Paso was also an internationally exhibited artist whose work, both in ink and paint, offers precisely rendered, dreamlike images that juxtapose and merge the real and fantastic.

3 As the earliest Surrealist and Dadaist art employed collage, irrationally juxtaposing pre-existing elements to create something new and inspired by the unconscious, so did Surrealist literature. One finds such juxtapositions in del Paso's writing. Here is a sentence from News from the Empire: "[The messenger] came, laden with memories and dreams, in a caravel whose sails were filled by a single gust of luminous wind pregnant with parrots."

4 There is a synergy, del Paso explains, between his writing and his painting: "A successful painting is a dream that dares to exist, or a nightmare. Very elaborate drawings tell us many things. In that they resemble literature, I think. This reality in which I write, and that which I paint help each other." Moreover, for del Paso, his painting is inseparable from his life, and a given painting no more than a part of the unfinishable painting that is life. In his words: "One paints not only when painting also when walking, when thinking, when sleeping. Each painting is a fragment of a painting of infinite dimensions that we never finish." 
5 Defending del Paso's writings from the charge that because they are "total novels" ("novelas totalas") they are insufficiently democratic, scholar Mark Daniel Anderson, in his essay "Modernism, Crisis, and the Ethics of Democratic Representation in Fernando del Paso's Total Novels," (Latin American Research Review, 2015, Vol.50, No.2, pp. 42-62), argues that such criticism does not apply to del Paso's novels which employ a modernist collage structure that promotes an "ethics that arises from the shared heterogeneity of daily life in the midst of crisis."

6 Happily, del Paso's art, both literary and visual, however Surreal, dreamlike, and fantastic, has a clarity and appeal that avoids such obscurantist scholarship. His total novels have points to make that are political as well as psychological. Tapping into the Freudian unconscious as Breton prescribed is all well and good, and del Paso has no trouble accessing his: "I dream that I paint and I paint the dream," he says in this interview, adding, "When I wake up on what side of reality will I be?" But del Paso in his fiction is also disavowing traditional interpretations of political ruptures - the repression of striking workers in 1959, the massacres of students in 1968, the French intervention in Mexico in the 1860s.

7 For del Paso, surrealist expression is both dream and political reality. Is it rhetorical license to say, pace Breton's Manifesto, that Surrealism is so broadly applied as a term that it really has no definitive meaning? It describes political and cultural rebellion as well as emotional and aesthetic expressions (or non-aesthetic as Breton disingenuously insisted). And del Paso, a Mexican, had unquestionably absorbed the deep history of Surrealism of his native land. It was to Mexico that Breton fled, as did Leonora Carrington and other European Surrealists, and where every variety of Surrealist expression flourished. Latin American magic realism characterizes its literature. Is it a stretch to see its revolutionary art as the metaphorical offspring of Frieda Kahlo's affair with Leon Trotsky?

8 Is it a further stretch to find a political view in del Paso's declaiming, "The monsters are with us, the artist doesn't imagine them" ? When I first heard those words from him twenty years ago, I recall that I smiled and had some vague picture of the mildly intimidating children's book drawings of Maurice Sendak or the anodyne puppets of Sesame Street. Later, after some reflection I considered that del Paso might have intended a sort of arch repudiation of Breton; specifically, it seemed he was turning away from the orthodox notions of surrealist creation through automatism, or by connecting with the spiritual in nature, or with the ancient artifacts of indigenous peoples, or through the application of chance in DaDa. I saw the remark as playful irony, more teasing than challenging, and didn't really give it much more thought until a few weeks ago when I visited the Surrealism exhibition at the Metropolitan Museum of Art.

9 Today I believe that I, too, can see the monsters del Paso alluded to. I suspect the warm, avuncular man in this interview was not remotely ironic when he observed that they are with us in our waking lives and not merely the products of our imagination, that the artist paints the monsters that haunt our days. I refer to the black and brownshirted (and orange-faced) monsters who would take our liberty and our lives. The flagwaving racists, the corrupt and self-dealing, speech and idea-suppressing, violent monsters that surround us and run our nations. The monstrous politicians, bought and paid for by powerful parochial interests who persuade ignorant voters with lies and Orwellian double-speak. Finally, the monstrous electorate, afraid of its own unaccessed 
unconscious as much as the imagined threats from some "other," eager to flee the frightening responsibility of democracy for the supposed protection of the autocrat.

\section{Transcription of the interview with del Paso} that doesn't happen when I'm writing. Afterwards they are so different--the pleasures-that we cannot compare them. and myself. And many many years later, when I was working at the BBC external services during the night shift... Well, it was not possible to read and listen, it was not possible to write and listen. But it was possible for me to hear the transmission and make my drawings.

17 I don't have any problem with that. Because I don't think much when I am drawing. One usually doesn't think much when drawing or painting--only when writing, of course.

arted with Indian ink with very, very small drawings. And they began to grow and to grow. And suddenly a friend of mine took them and took them to the ICA, the Institute of Contemporary Arts in London. The lady who was the curator, she liked them very much. And so I had my first exhibition there in London in a very important Institute. Together with Jim Dine.

\section{The relationship between writing and drawing}

Let me tell you that I cannot let's say draw in the morning and write in the afternoon Or draw one week and the following week write. No. Once I start one of those two things, if I start drawing I have immersed myself in that world and I continue for two, three, four, or five months. If I start to write I have to immerse myself also for three, four, five, six months. 

very happy. But once I begin to use color I have nightmares, and then I cannot sleep well. Color is very conflictive to me. I don't know why. I have nightmares, but with Indian ink, life is wonderful.

\section{Observations on art}

A painting is, in the first and last instance, an endless struggle between darkness and light, from which light always emerges triumphant. Even if we paint a completely black picture, in order to see it, we have to surround it with light.

How to imagine an unknown color? If paradise exists, it should include a trip to the infrared world. And another beyond the ultraviolet world.

A successful painting is a dream that dares to exist, or a nightmare. Very elaborate drawings tell us many things. In that they resemble literature, I think. This reality in which I write, and that which I paint help each other.

Thanks to the invention of photography, painting found a thousand new languages.

monsters do not pursue me, they walk with me all the time. .Monsters always exist: in the air, on paper. The artist to draw them captures them, copies them--he doesn't invent them.

28 At times, I feel that my hand when I draw, has its own will.

29 When I use blue I believe it is the most beautiful color that exists. The same thing happens to me with orange, with green, with lilac. Each color is the most beautiful color that exists. All colors combine with all others. There are no poor combinations, only poor imaginations.

30 Literature and music exist in time. They have a beginning and end. Painting and sculpture exist in space. Where does the Venus de Milo begin? In her navel? In her breasts? Or in her head? Where does an abstract painting begin? In the lower left corner or in the center?

31 A painting not only recreates exterior reality, but also interior reality. I dream that I paint and I paint the dream. When I wake up on what side of reality will I be?

\section{AUTHOR}

\section{DONALD FRIEDMAN}

Donald Friedman, a novelist, essayist, sometime lawyer, but never a scholar, somehow produced the internationally acclaimed The Writer's Brush: Paintings, Drawings, and Sculpture by Writers. That book brought together the visual art of more than 200 of the world's great writers. To 
celebrate its publication, he planned a modest exhibition of writer-art which, with the assistance of John Wronoski, antiquarian bookseller and art dealer, was enlarged to include dozens of poets and writers somehow omitted from the book, and became a museum-scale show (https:// donaldfriedman.com/books/the-writers-brush-the-exhibition/). Along the way to the book and the exhibition, Friedman interviewed a number of writer-artists on camera. Excerpts of those interviews are being posted on Interfaces' website, accompanied by transcripts and introductions. For Interfaces contributors and friends interested in acquiring copies of The Writer's Brush direct from the author at a deep discount, please contact him through his website, https://donaldfriedman.com/books/the-writers-brush/ 